\title{
Solar to Chemical Conversion Using Metal Nanoparticle Modified Low-Cost Silicon Photoelectrode
}

\author{
Shinji Yae \\ University of Hyogo \\ Japan
}

\section{Introduction}

The storage of solar energy is one of the key technologies in making solar energy a major energy resource for humans (Turner et al., 2004). Solar hydrogen, which is produced by splitting water using solar energy, can be considered the perfect renewable energy. Hydrogen is an energy medium that can be easily stored and transported. It can generate not only thermal energy but also electricity using fuel cells and mechanical energy using hydrogen engines. Hydrogen returns to water via such energy generation. Therefore, solar hydrogen can form the basis of a clean, renewable energy cycle.

\subsection{Solar hydrogen production with photoelectrochemical solar cells}

Solar hydrogen production, that is, water splitting by photoelectrochemical solar cells equipped with a titanium dioxide $\left(\mathrm{TiO}_{2}\right)$ photoelectrode has been attracting much attention since Fujishima and Honda's report in 1972 (Fujishima \& Honda, 1972). Photoelectrochemical solar cells have important and unique features (Licht, 2002, Nakato, 2000). They are fabricated simply by immersing a semiconductor electrode and a counterelectrode into an electrolyte solution (Fig. 1). They can convert solar energy not only to electricity (Fig. 1a) but also directly to storable chemical energy (Figs. 1b and 2) such as water splitting into hydrogen and oxygen (Arakawa et al., 2007, Fujishima \& Honda, 1972, Grätzel, 1999, Khaselev \& Turner, 1998, Lin et al., 1998, Miller et al., 2005, Park \& Bard, 2005, Sakai et al., 1988), the decomposition of hydrogen iodide into hydrogen and iodine (Nakato et al., 1998, Nakato, 2000, Takabayashi et al., 2004, 2006), and the reduction of carbon dioxide to hydrocarbons or carbon monoxide (Hinogami et al., 1997, 1998). For the photovoltaic photoelectrochemical solar cell (Fig. 1a), two electrodes are immersed in a redox electrolyte solution. Opposite reactions such as the oxidation of the reductant to an oxidant on an n-type semiconductor electrode and the reduction of the oxidant to the reductant on the counterelectrode occur through solar illumination. Thus, the composition of redox electrolyte solution does not change, and only electricity is obtained as usual solid-state solar cells. For the photo to chemical conversion type of photoelectrochemical solar cells (Fig. 1b), different reactions occur on the electrodes, for example, the oxidation of iodide ions to iodine (triiodide ions) and 
hydrogen evolution. This decomposition of hydrogen iodide is an 'up-hill' reaction. Thus, solar energy is directly converted to chemical energy using this type of photoelectrochemical solar cells. The junction of an electrolyte solution and a semiconductor can generate a high-energy barrier, thus reaching a high photovoltage level even with a low-cost, low-quality semiconductor. However, water splitting using titanium dioxide encounters serious difficulty in achieving hydrogen evolution. There are three solutions to this difficulty: using another semiconductor with an energy band gap that is wider than titanium dioxide; using a multi-photon system equipped with multiphotoelectrodes in series or a tandem-type photoelectrode; and using a hydrogenproducing semiconductor, such as silicon ( $\mathrm{Si})$, and an oxidation reaction other than oxygen evolution, such as oxidation of iodide ions into iodine.
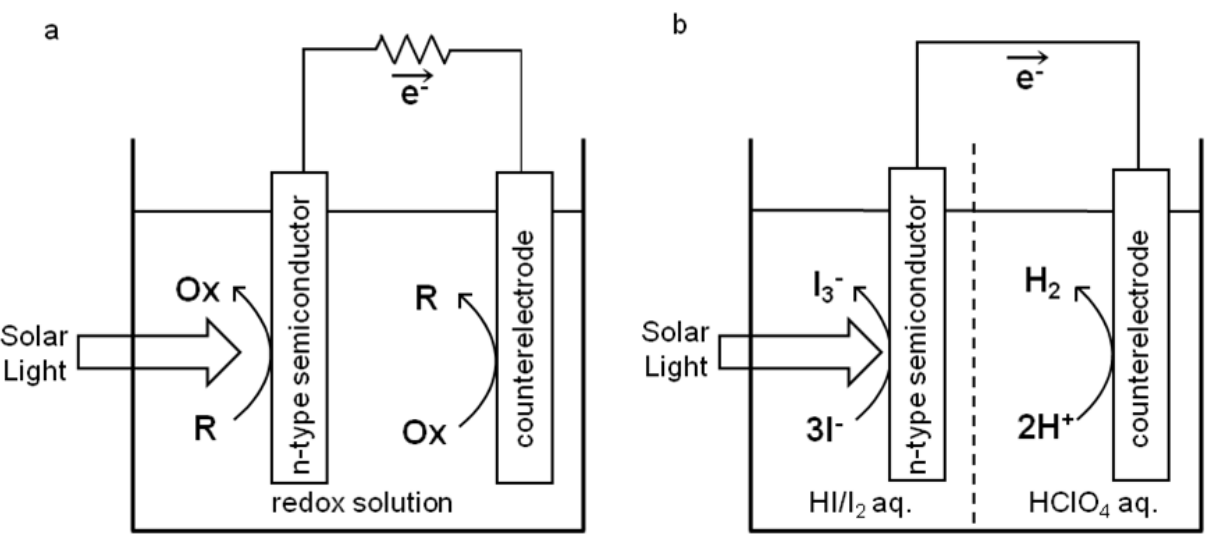

Fig. 1. Schematic illustrations of PEC solar cells. a) photovoltaic type; b) solar-to-chemical conversion type.

The Gibbs energy change for decomposition of hydrogen iodide (HI) into hydrogen $\left(\mathrm{H}_{2}\right)$ and iodine $\left(\mathrm{I}_{2}\right)$ (triiodide ion $\left(\mathrm{I}_{3}^{-}\right)$) in an aqueous solution (see equations 1, 2 and 3 ) is smaller than that for water splitting. Thus, silicon photoelectrodes, which have a narrower energy band gap than titanium dioxide, can decompose hydrogen iodide with no external bias (Figs. 1b, 2 and equations (1)-(3)). The efficiency of a solar-to-chemical conversion via the photoelectrochemical decomposition of hydrogen iodide using single-crystalline silicon electrodes reached 7.4\% (Nakato, 2000, Nakato et al., 1998, Takabayashi et al., 2004, 2006). Fuel cells using hydrogen gas and iodine solution can generate electricity via the reverse reaction of hydrogen iodide decomposition (equation (3)). Therefore, this system can form a solar energy cycle in a similar manner as the cycle consisting of water splitting and hydrogen-oxygen fuel cells.

$$
\begin{aligned}
\text { Anode } & 3 \mathrm{I}^{-}+2 \mathrm{~h}^{+} \rightarrow \mathrm{I}_{3^{-}} \\
\text {Cathode } & 2 \mathrm{H}^{+}+2 \mathrm{e}^{-} \rightarrow \mathrm{H}_{2} \\
\text { Total reaction } & 2 \mathrm{HI} \rightarrow \mathrm{H}_{2}+\mathrm{I}_{2}\left(\mathrm{I}_{3}{ }^{-}\right)
\end{aligned}
$$



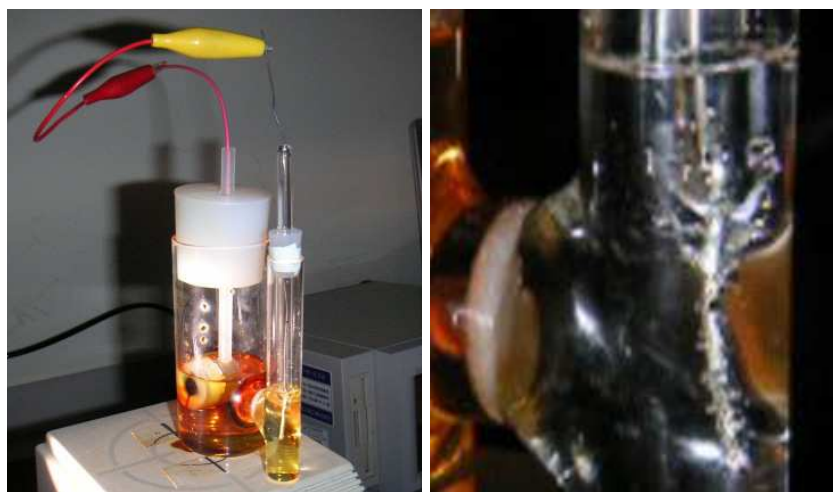

Fig. 2. Photoelectrochemical solar cell produces hydrogen gas via photodecomposition of hydrogen iodide with no external bias.

\subsection{Metal nanoparticle modification of semiconductor electrode}

Unfortunately, bare semiconductors can easily corrode or be passivated in aqueous solutions, and do not have enough catalytic activity for electrochemical reactions. Modifying the semiconductor surface with metal nanoparticles eliminates these problems without lowering the high energy barrier feature (Allongue et al., 1992, Hinogami et al., 1997, 1998, Jia et al., 1996, Nakato, 2000, Nakato et al., 1988, 1998, Nakato \& Tsubomura 1992, Takabayashi et al., 2004, 2006, Yae et al., 1994a). The operation principle of this type of solar cells is explained as follows (Nakato et al., 1988, Nakato \& Tsubomura 1992). Figure 3 shows a schematic illustration of cross section of a platinum (Pt)-nanoparticle modified n-type silicon (n-Si) photoelectrode. Photogenerated holes in $\mathrm{n}-\mathrm{Si}$ transfer to the redox solution through the $\mathrm{Pt}$ particles, thus leading to a steady photocurrent. With no Pt particle, the photocurrent decays rapidly. The surface band energies of $\mathrm{n}-\mathrm{Si}$ are modulated by the deposition of $\mathrm{Pt}$ particles. However, the effective barrier height is nearly the same as that for bare n-Si in case where the size of the Pt particles (or more correctly, the size of the areas of direct Pt-Si contacts) is small enough, much smaller than the width of the space charge layer. Thus, a very high barrier height, nearly equal to the energy band-gap, can be obtained if one chooses a electrochemical reaction with an enough high potential. Also, a major part of the n-Si surface is covered with a thin Si-oxide layer and passivated, and hence the electron-hole recombination rate at the n-Si surface is maintained quite low. For these reasons, very high photovoltage can be generated.

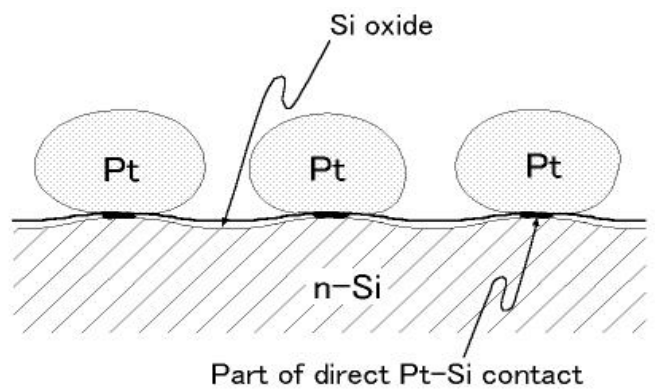

Fig. 3. Schematic illustration of cross section of a Pt-nanoparticle-modified n-Si photoelectrode. 
In this study, Pt-nanoparticle modified multicrystalline $\mathrm{Si}$ wafers and microcrystalline $\mathrm{Si}$ $(\mu \mathrm{c}-\mathrm{Si}: \mathrm{H})$ thin films (Yae et al., 2007a, b) are used as photoelectrodes in the photodecomposition of hydrogen iodide for low-cost and efficient production of solar hydrogen. We also attempt solar water splitting using a multi-photon system equipped with the microcrystalline Si thin film and metal-oxide photoelectrodes in series (Yae et al., 2007b).

\section{Platinum nanoparticle modified porous multicrystalline silicon}

Multicrystalline silicon is the most common material of the present conventional solar cells. We applied multicrystalline Si to solar hydrogen production by the photodecomposition of hydrogen iodide. To improve the conversion efficiency and stability of photoelectrochemical solar cells, multicrystalline n-type Si wafers were catalyzed with platinum nanoparticles and antireflected with a porous Si layer. The $\mathrm{Pt}$ nanoparticles were deposited on the multicrystalline Si substrates by electroless displacement deposition immersing substrates in a metal salt solution including hydrofluoric acid (Yae et al., 2006a, 2007c, 2008). The porous Si layers were formed by metal-particle-assisted hydrofluoric acid etching immersing metalparticle modified Si wafers in a hydrofluoric acid solution (Yae et al., 2003, 2006a, 2009).

\subsection{Platinum nanoparticle formation by electroless displacement deposition}

The metal nanoparticles play a tremendously important role in photoelectrochemical solar cells for photovoltaic and photochemical conversion of solar energy (Nakato et al., 1988, Nakato \& Tsubomura 1992). The kind, particle density and size of nanoparticles influence the stability and conversion efficiency of solar cells. Thus, controlling the size and distribution density (particle density) of metal nanoparticles on semiconductor, multicrystalline $\mathrm{Si}$ in this case, is important for obtaining efficient photoelectrochemical solar cells. As well-controlled and low-cost methods of depositing metal nanoparticles on $\mathrm{Si}$, we have been utilizing several methods such as simply dropping a solution of colloidal metal particles (Yae et. al., 1994a), preparing a Langmuir-Blodgett layer of nanoparticles (Jia et al., 1996, Yae et. al., 1994b, 1996), electrodeposition (Yae et. al., 2001, 2008), and electroless displacement deposition (Yae et al., 2007c, 2008). We choose the electroless displacement deposition to prepare Pt nanoparticles on multicrystalline Si wafers (Yae et al., 2006a). The electroless deposition of metals is a simple process involving only the immersion of substrates into metal-salt solutions. The electroless deposition is classified into autocatalytic and displacement depositions (Paunovic \& Schlesinger, 2006). The electroless displacement deposition of metals onto Si uses a simple solution containing metal-salt and hydrofluoric acid. The deposition reaction is local galvanic reaction expressed by equations (4) and (5) consisting of the cathodic deposition of metal on Si accompanying positive hole injection into the valence band of $\mathrm{Si}$ and the anodic dissolution of Si. Various kinds of metals can be deposited on Si using this method (Chemla et al., 2003, Gorostiza et al., 1996, 2003, Nagaraha et al., 1993, Yae et al., 2007c, 2008).

Deposition of metal on Si:

$$
\mathrm{Mn}^{+} \rightarrow \mathrm{M}+\mathrm{nh}^{+}
$$

Anodic oxidation and dissolution of Si in an hydrofluoric acid solution:

$$
\mathrm{Si}+4 \mathrm{HF}_{2}^{-}+2 \mathrm{~h}^{+} \rightarrow \mathrm{SiF}_{6}{ }^{2-}+2 \mathrm{HF}+\mathrm{H}_{2}
$$

or 


$$
\begin{gathered}
\mathrm{Si}+2 \mathrm{H}_{2} \mathrm{O}+4 \mathrm{~h}^{+} \rightarrow \mathrm{SiO}_{2}+4 \mathrm{H}^{+} \\
\mathrm{SiO}_{2}+6 \mathrm{HF} \rightarrow \mathrm{SiF}_{6}^{2-}+2 \mathrm{H}^{+}+2 \mathrm{H}_{2} \mathrm{O}
\end{gathered}
$$

Non-polished multicrystalline n-type Si wafers (cast, ca. $2 \Omega \mathrm{cm}, 0.3 \mathrm{~mm}$ thick) were washed with acetone, and etched with $1 \mathrm{~mol} \mathrm{dm}^{-3}$ sodium hydroxide or potassium hydroxide solution at $353 \mathrm{~K}$ for saw damage layer removal. Before deposition of Pt particles, the wafers were treated by one of two pretreatment methods (hereafter, we call these pretreatments method A and method B). Method A: the wafers were washed with acetone, immersed in a CP-4A (a mixture of hydrofluoric acid, nitric acid, acetic acid, and water) solution for three min, and then immersed in a $7.3 \mathrm{~mol} \mathrm{dm}^{-3}$ hydrofluoric acid solution for two min. Method B: the wafers were immersed in $14 \mathrm{~mol} \mathrm{dm}^{-3}$ nitric acid at $353 \mathrm{~K}$ for 30 min after method A treatment. The multicrystalline Si wafer was immersed in a $1.0 \times 10^{-3} \mathrm{~mol} \mathrm{dm}^{-3}$ hexachloroplatinic (IV) acid solution containing $0.15 \mathrm{~mol} \mathrm{dm}^{-3}$ hydrofluoric acid at $313 \mathrm{~K}$ for $30-120 \mathrm{~s}$.
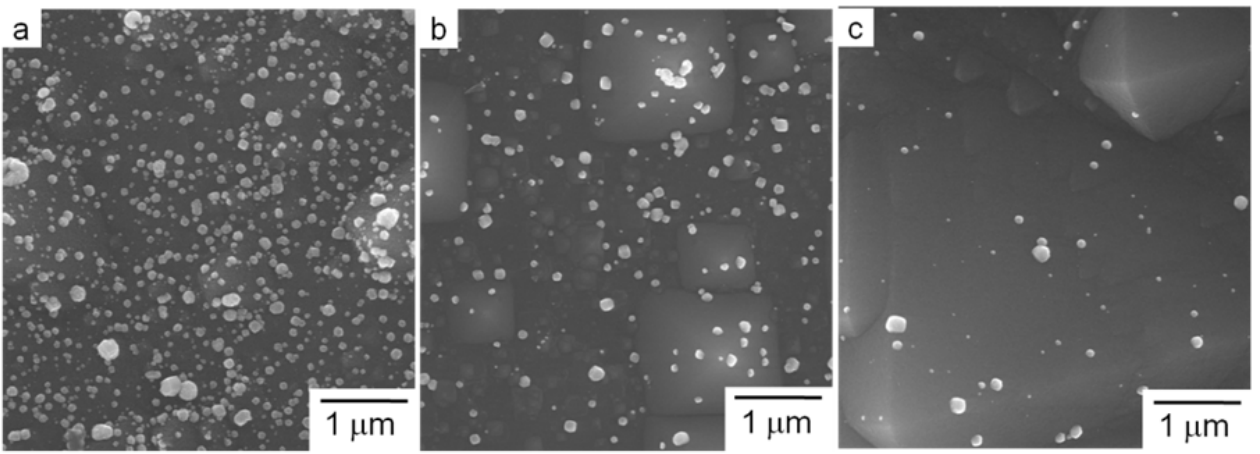

Fig. 4. Typical scanning electron microscopic (SEM) images of multicrystalline n-Si wafers pretreated by method A (image a) or B (b and c) and immersed in the Pt displacement deposition solution for 120 ( $a$ and $b$ ) or $30 \mathrm{~s}(\mathrm{c})$.

Figure 4 shows typical scanning electron microscopic (SEM) images of $\mathrm{Pt}$ deposited multicrystalline Si wafers. Spherical Pt-nanoparticles were sparsely scattered on the multicrystalline Si surfaces. Thin Si oxide layer formed by immersing the multicrystalline Si wafers in nitric acid solution (method B) decreased the particle density from $4 \times 10^{9}$ to $0.9 \times 10^{9}$ $\mathrm{cm}^{-2}$ (Figs. $4 \mathrm{a}$ and b). Shortening the immersion time from 120 to $30 \mathrm{~s}$ decreased the average particle size from 87 to $67 \mathrm{~nm}$ (Figs. $4 \mathrm{~b}$ and c). The size and particle density of electrolessly deposited Pt nanoparticles on multicrystalline Si can be controlled by changing the deposition conditions. This is consistent with our previously reported results on singlecrystalline silicon aside from high particle density (Yae et al., 2007c).

\subsection{Porous silicon formation by metal-particle-assisted hydrofluoric acid etching}

The antireflection of the semiconductor surface is an effective method for improving the energy conversion efficiency of solar cells (Sze, 1981, Nelson, 2003). The surface texturization by anisotropic etching is a common antireflection method for single crystalline $\mathrm{Si}$ solar cells. However, multicrystalline Si cannot be uniformly texturized by the anisotropic etching caused by its variety of orientations of crystallites. The metal-particle-assisted hydrofluoric acid etching can form both macroporous and microporous layers on 
multicrystalline Si wafers, which are modified with fine metal particles, by simply immersing the wafers in an hydrofluoric acid solution without a bias and a particular oxidizing agent (Yae et al. 2006a, 2009). In previous papers, we reported that porous layer formation by this etching for $24 \mathrm{~h}$ decreased the reflectance of $\mathrm{Si}$ and increased the solar cell characteristics, which are not only photocurrent density but also photovoltage (Yae et al. 2003, 2005, 2006a, 2009).

\subsubsection{Etching mechanism}

The metal-particle-assisted hydrofluoric acid etching of Si proceeds by a local galvanic cell mechanism requiring photoillumination onto Si or dissolved oxygen in the solution (Yae et al. 2005, 2007d, 2009, 2010). Figure 5 shows a schematic diagram of n-Si and electrochemical reaction (equations (5), (6) and (7)) potential in a hydrofluoric acid solution. The local cell reaction consists of anodic dissolution of Si (equation (5)) and cathodic reduction of oxygen (equation (6)) and/or protons (equation (7)) on catalytic $\mathrm{Pt}$ particles. Under the photoillumination, photogenerated holes in the Si valence band anodically dissolve Si on the whole photoirradiated surface of Si. Under the dark condition, the etching proceeds by holes injected into the Si valence band with only cathodic reduction of oxygen on Pt particles, and thus the etching is localized around the Pt particles. The localized anodic dissolution produces macropores, which have Pt particles on the bottom, on the Si surface as shown in Fig. 6. We previously revealed two points about metal-particle-assisted hydrofluoric acid etching of Si: 1) the etching rate increased with photoillumination intensity on Si wafers and dissolved oxygen concentration in hydrofluoric acid solution; and 2) the time dependence of photoillumination intensity on the Si sample in the laboratory, which is ca. $0.2 \mathrm{~mW} \mathrm{~cm}-2$ illumination for $6 \mathrm{~h}$, dark condition for $12 \mathrm{~h}$ and then ca. $0.2 \mathrm{~mW} \mathrm{~cm}^{-2}$ illumination for $6 \mathrm{~h}$, is suitable to produce the macro- and microporous combined structure effective for improving

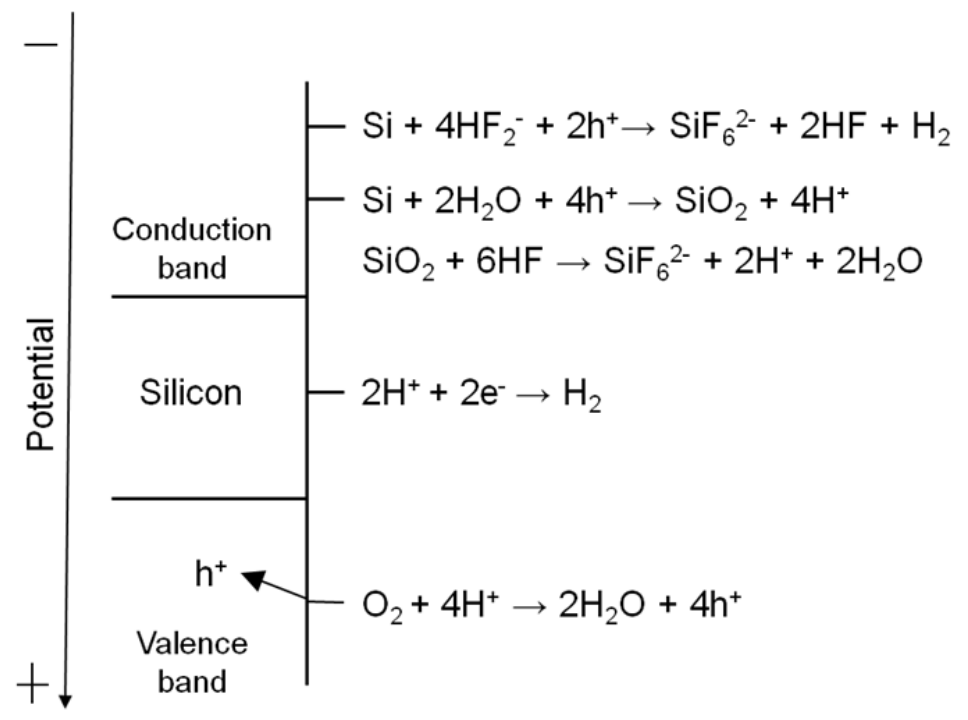

Fig. 5. Schematic diagram of silicon and electrochemical reaction potential in a hydrofluoric acid solution. 
the solar cell characteristics (Yae et al. 2005, 2006b, 2009). In this section, we applied this method to the Pt-nanoparticle-modified multicrystalline n-Si to improve the solar cell characteristics, and attempted to shorten the etching time by controlling etching conditions such as the photoillumination intensity and the dissolved oxygen concentration.

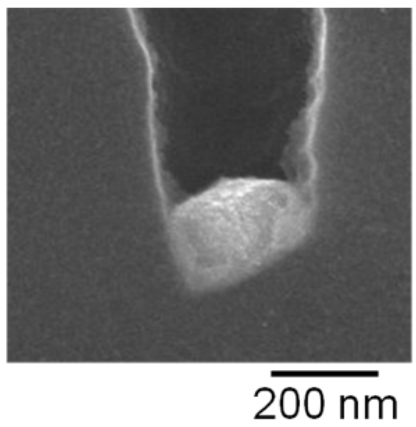

Fig. 6. Typical cross-sectional scanning electron micrograph of silicon macropore having a Pt particle on the bottom.

\subsubsection{Porous structure control}

The Pt-nanoparticle modified multicrytalline n-Si wafers were immersed in a $7.3 \mathrm{~mol} \mathrm{dm}^{-3}$ hydrofluoric acid aqueous solution at $298 \mathrm{~K}$. In some cases, oxygen gas bubbling was applied to the solution, and/or the n-Si wafers were irradiated with a tungsten-halogen lamp during immersion in the solution in a dark room. The reflectance of Si wafers was measured using a spectrophotometer in the diffuse reflection mode with an integrating sphere attachment.

\begin{tabular}{|c|c|c|c|c|}
\hline $\begin{array}{c}\text { Preparation } \\
\text { conditions }\end{array}$ & Pretreatment & $\begin{array}{c}\mathrm{Pt} \\
\text { deposition } \\
\text { time (s) }\end{array}$ & $\begin{array}{c}\text { Prorous layer formation (matal- } \\
\text { particle-assisted hydrofluoric } \\
\text { acid ethcing) conditions }\end{array}$ & $\begin{array}{c}\text { Total etching } \\
\text { time }(\mathrm{h})\end{array}$ \\
\hline a & A & 120 & without light control for $24 \mathrm{~h}$ & 24 \\
\hline $\mathrm{b}$ & $\mathrm{B}$ & 120 & without light control for $24 \mathrm{~h}$ & 24 \\
\hline c & B & 120 & $\begin{array}{l}\text { under } 40 \mathrm{~mW} \mathrm{~cm}^{-2} \text { with no } \\
\text { bubbling for } 3 \mathrm{~h}\end{array}$ & 3 \\
\hline d & B & 120 & $\begin{array}{c}40 \mathrm{~mW} \mathrm{~cm}^{-2} \text { with no bubbling for } \\
2 \mathrm{~h} \text { and then in the dark with } \\
\text { oxygen bubbling for } 4 \mathrm{~h}\end{array}$ & 6 \\
\hline e & B & 120 & $\begin{array}{l}\text { adding under } 40 \mathrm{~mW} \mathrm{~cm}^{-2} \text { with } \\
\text { oxygen bubbling for } 0.5 \mathrm{~h} \text { to } \\
\text { condition } \mathrm{d}\end{array}$ & 6.5 \\
\hline $\mathrm{f}$ & B & 60 & $\begin{array}{c}40 \mathrm{~mW} \mathrm{~cm}^{-2} \text { with no bubbling for } \\
2 \mathrm{~h} \text { and then in the dark with } \\
\text { oxygen bubbling for } 4 \mathrm{~h}\end{array}$ & 6 \\
\hline g & B & 60 & $\begin{array}{l}\text { adding under } 40 \mathrm{~mW} \mathrm{~cm}^{-2} \text { with } \\
\text { oxygen bubbling for } 0.5 \mathrm{~h} \text { to } \\
\text { condition } \mathrm{f}\end{array}$ & 6.5 \\
\hline
\end{tabular}

Table 1. Preparation conditions of Pt nanoparticle modified porous multicrystalline n-Si 
The deposition conditions of Pt-nanoparticles and metal-particle-assisted hydrofluoric acid etching conditions are listed in Table 1. Figure 7 shows typical scanning electron microscopic images of multicrystalline n-Si wafers that were pretreated by method A (image a) or B (image b) and metal-particle-assisted hydrofluoric acid etching without light control for $24 \mathrm{~h}$ (conditions a and b in Table 1). Macropores, whose diameter is $0.3-1 \mu \mathrm{m}$, were formed on whole surfaces of multicrystalline n-Si wafers. The density of pores, i.e. porosity, of n-Si wafer pretreated by method B is lower than that for method A. This is consistent with the Pt particle density on multicrystalline Si surface before etching (Fig. 4a and b). Both samples showed an orange photoluminescence under UV irradiation, thus microporous layers were formed on both samples.
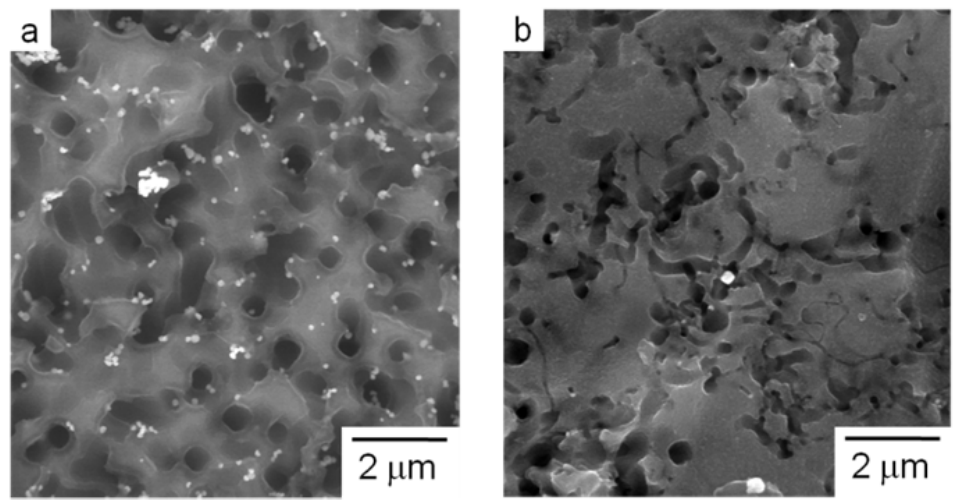

Fig. 7. Typical scanning electron microscopic images of Pt nanoparticle modified porous multicrystalline $\mathrm{n}-\mathrm{Si}$. Preparation conditions: images $\mathrm{a}$ and $\mathrm{b}$ are for conditions $\mathrm{a}$ and $\mathrm{b}$ in Table 1, respectively.

Figure 8 shows typical scanning electron microscopic images of multicrystalline n-Si that were pretreated by method B and metal-particle-assisted hydrofluoric acid etching under control of the photoillumination and the dissolved oxygen concentration (conditions $\mathrm{c}$ to $\mathrm{g}$ in Table 1). A microporous layer giving photoluminescence and no macropores was formed by etching under photoillumination without any gas bubbling estimated dissolved oxygen concentration of solution is ca. 5 ppm (Fig. 8a, condition c). The etching under the dark condition with oxygen gas bubbling (the solution was saturated with oxygen) after the etching under photoillumination produced macro- and microporous combined structure on the multicrystalline n-Si wafer (Fig. 8b, condition d). The morphology of the Si surface is similar to that formed by the etching without light control and gas bubbling for $24 \mathrm{~h}$ (Fig. $7 \mathrm{~b}$, condition b). Addition of the photoillumination with oxygen bubbling to the preceding conditions enlarged the macropore size and microporous layer thickness (Fig. 8c, condition e). Shortening the immersion time of multicrystalline $\mathrm{n}$-Si wafers in the $\mathrm{Pt}$ displacement deposition solution, i.e. reduction of particle size and particle density of $\mathrm{Pt}$ on the wafers, reduced the number of macropores on the etched n-Si wafers (Figs. $8 \mathrm{~d}$ and e, conditions $\mathrm{f}$ and $\mathrm{g}$, respectively). The structure change in the porous layer of multicrystalline $\mathrm{n}$-Si by changing the photoillumination intensity and dissolved oxygen concentration is consistent with our previously reported results on single crystalline n-Si (Yae et al., 2005, 2006b, 2009). 

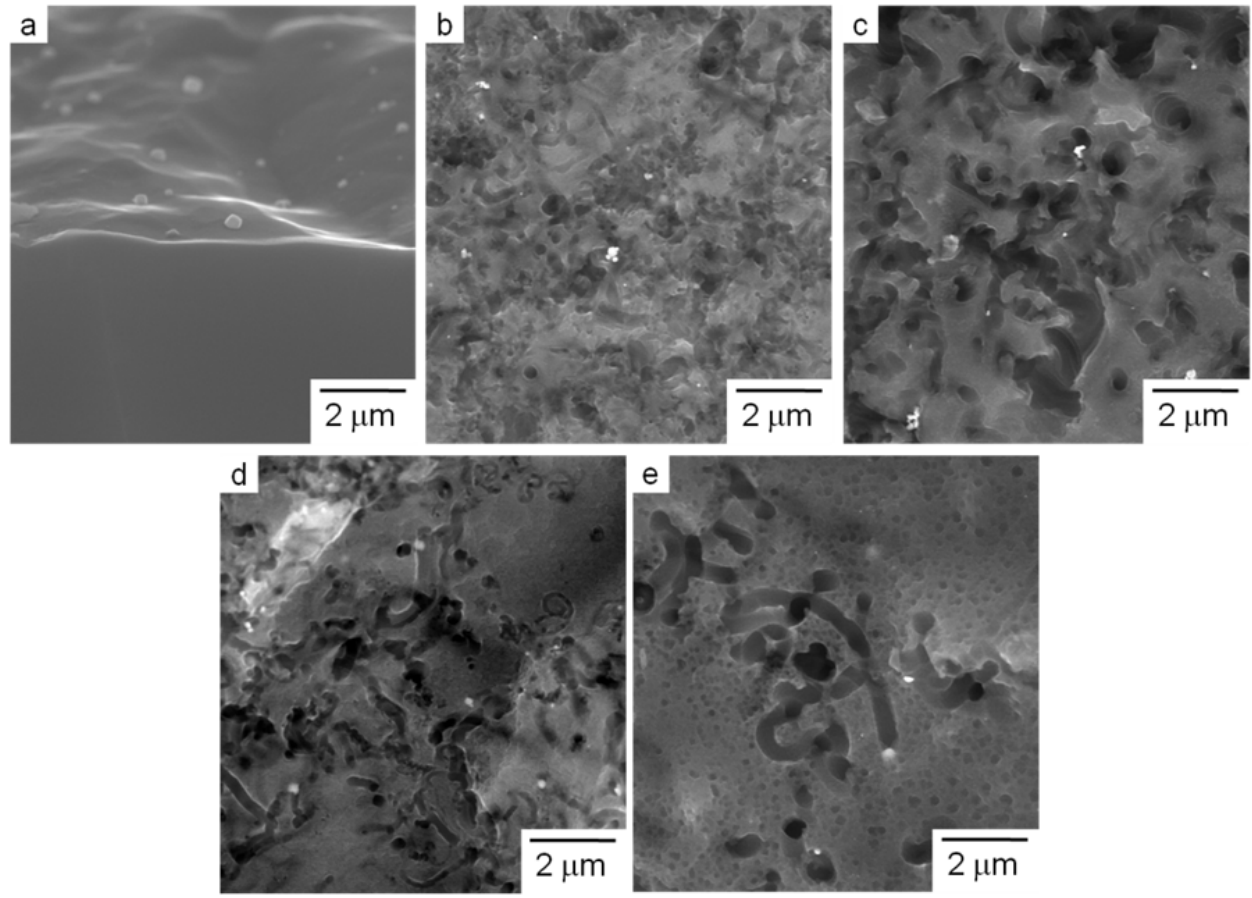

Fig. 8. Typical scanning electron microscopic images of Pt nanoparticle modified porous multicrystalline n-Si. Preparation conditions: images a, b, c, d, and e are for conditions c, d, $\mathrm{e}, \mathrm{f}$, and $\mathrm{g}$ in Table 1, respectively.

\subsubsection{Antireflection effect}

The macroporous layer formation changed the surface color of multicrystalline n-Si wafers to dark gray. Figure 9 shows the reflectance spectra of multicrystalline n-Si wafers. The porous layer prepared by the etching without light control and gas bubbling for $24 \mathrm{~h}$ reduced the reflectance from over 30\% to under 6.2\% (curves a and b) (Yae et al., 2006a, 2009). The porous layers prepared by the etching under the conditions $\mathrm{d}$ and $\mathrm{g}$ of Table 1 gave reflectance between 8 and 17\% (curves $c$ and d). This value is higher than that of the wafer prepared under the non-controlled conditions, but much lower than the non-etched wafer.

\subsection{Photovoltaic photoelectrochemical solar cells}

To evaluate electrical characteristics of photoelectrodes, we prepared photovoltaic photoelectrochemical solar cells (Fig. 1a) equipped with the Pt-nanoparticle modified porous multicrystalline n-Si photoelectrode. The multicrystalline n-Si electrode and Pt-plate counterelectrode were immersed in a redox electrolyte solution. Just before measuring the solar cell characteristics, the multicrystalline n-Si electrode was immersed in a $7.3 \mathrm{~mol} \mathrm{dm}^{-3}$ hydrofluoric acid solution for two min under the elimination of dissolved oxygen by bubbling pure argon gas into the solution. This treatment is important to obtain high photovoltage caused by halogen atom termination of Si surface as mentioned below. A mixed solution of $7.6 \mathrm{~mol} \mathrm{dm}^{-3}$ hydroiodic acid (HI) and $0.05 \mathrm{~mol} \mathrm{dm}^{-3}$ iodine $\left(\mathrm{I}_{2}\right)$ was used 
as a redox electrolyte solution of the photovoltaic photoelectrochemical solar cell. Photocurrent density versus potential $(j-U)$ curves were obtained with a cyclic voltammetry tool. The potential of the $\mathrm{n}-\mathrm{Si}$ wafer was measured with respect to the $\mathrm{Pt}$ counterelectrode. The multicrystalline $\mathrm{n}-\mathrm{Si}$ was irradiated with a solar simulator (AM1.5G, $100 \mathrm{~mW} \mathrm{~cm}-2$ ) through the quartz window and a redox electrolyte solution ca. $3 \mathrm{~mm}$ thick.

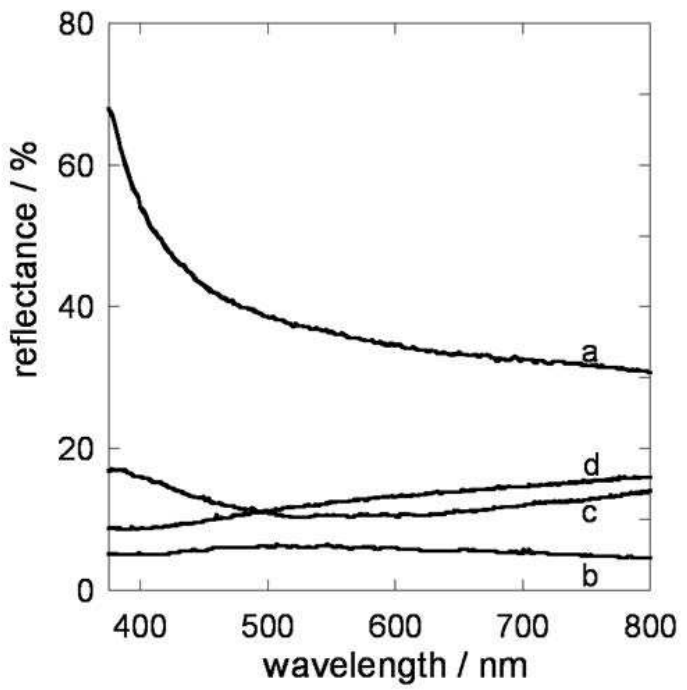

Fig. 9. Reflectance spectra of multicrystalline n-Si wafers: curve a after immersion in sodium hydroxide solution for saw damage layer removal; b, c, and d prepared under the conditions a, $d$, and $g$ in Table 1 , respectively.

\subsubsection{Effect of particle density and size of platinum nanoparticles}

Figure 10 show typical photocurrent density versus potential $(j-U)$ curves of Pt-nanoparticle modified multicrystalline n-Si photoelectrodes having no porous layer pretreated under the same conditions as the specimens of Fig. 4 . The decrease in particle density and size of Ptnanoparticles increased the open-circuit photovoltage $\left(V_{\mathrm{OC}}\right)$ and short-circuit photocurrent density (jsc) of photovoltaic photoelectrochemical solar cells from curve a to curve c of Fig. 10. Thus, the conversion efficiency $\left(\eta^{S}\right)$ of the solar cells increased from $3.8 \%$ to $5.0 \%$.

The reason for the increase in photocurrent density of the photoelectrochemical solar cells is the decrease of surface coverage of Pt-nanoparticles on Si. The surface coverage is $20 \%$ and $5 \%$ for Fig. 4a and b, respectively. This decrease is expected to increase the intensity of solar light reaching the Si surface by $19 \%$. This is almost consistent with the increase in the shortcircuit photocurrent density by $17 \%$. The average open-circuit photovoltage of 12 samples is $0.42 \mathrm{~V}$. This is lower than that for Pt-nanoparticle-electrolessly-deposited single crystalline $\mathrm{n}$-Si electrodes ( $0.50 \mathrm{~V}$ in the average of 76 samples). This is explained by the following two reasons. 1) Lower quality of multicrystalline Si than single crystalline: The characteristics of multicrystalline Si solar cells are commonly lower than those of single crystalline. Thus, not only photovoltage but also the short-circuit photocurrent density and fill factor (F.F.) of photoelectrochemical solar cells are $12.1 \mathrm{~mA} \mathrm{~cm}-2$ and 0.57 lower than those of single 
crystalline (18.3 mA cm-2 and 0.60 on average, respectively). 2) Insufficient density of termination of Si surface bonds with iodine atoms: The termination of Si surface bonds with iodine atoms shifts the flat band potential of $\mathrm{Si}$ toward negative, and thus increases the photovoltage of photoelectrochemical solar cells using hydroiodic acid and iodine redox electrolyte (Fujitani et al., 1997, Ishida et al., 1999, Yae et al., 2006a, Zhou et al., 2001). An electrolyte solution of $8.6 \mathrm{~mol} \mathrm{dm}-3$ hydrobromic acid $(\mathrm{HBr})$ and $0.05 \mathrm{~mol} \mathrm{dm}^{-3}$ bromine $\left(\mathrm{Br}_{2}\right)$ has sufficient negative redox potential to generate high open-circuit photovoltage without the termination. Using the hydrobromic acid and bromine electrolyte solution increases the photovoltage by $0.06 \mathrm{~V}$ for multicrystalline and $0.03 \mathrm{~V}$ for single-crystalline $\mathrm{n}$-Si electrodes from those using hydroiodic acid and iodine electrolyte solution. This result indicates that the density of the termination of multicrystalline n-Si surface bonds with iodine atoms is insufficient for generating high photovoltage.

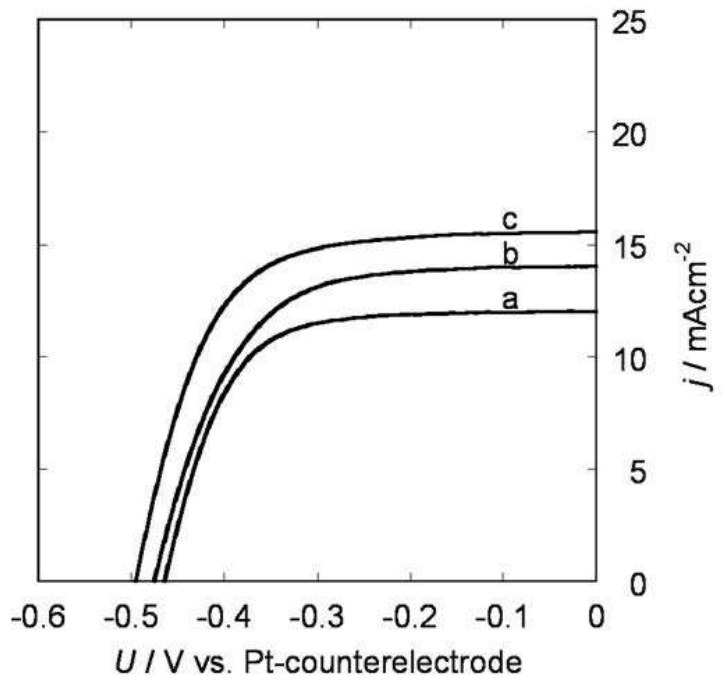

Fig. 10. Photocurrent density versus potential $(j-U)$ curves of photovoltaic photoelectrochemical solar cells equipped with Pt-nanoparticle modified multicrystalline n-Si photoelectrode having no porous layer pretreated under the same conditions as the specimens of Fig. 4. Pretreatment: method A (image a), B (b and c); Pt deposition time: 120 (a and b), $30 \mathrm{~s}$ (c).

\subsubsection{Effect of porous layer}

Table 2 and Figure 11 indicate the average characteristics and typical photocurrent density versus potential $(j-U)$ curves of photovoltaic photoelectrochemical solar cells equipped with a Pt-nanoparticle modified porous multicrystalline n-Si electrode prepared under the conditions listed in Table 1. The characteristics of photoelectrodes prepared under the conditions a and $b$ as those for the wafers indicated in Fig. 7 show that the combination of the controlling particle density and size of Pt particles, and the formation of porous layer using metal-particle-assisted etching obtained a large increase in the conversion efficiency $\left(\eta^{\varsigma}\right)$ from $3.8 \%$ for curve a in Fig. 10 and $2.9 \%$ in average of 12 samples to $5.1 \%$ in the average (Table 2). The formation of 
continuous microporous layer (Figs. 8a and 11a, and condition c in Table 1) increased photovoltage $\left(V_{\mathrm{OC}}\right)$, and decreased fill factor (F.F.) of the solar cells. The formation of macroand microporous combined structure (Figs. $8 \mathrm{~b}$ and $\mathrm{c}$, and conditions $\mathrm{d}$ and e in Table 1, respectively) increased photocurrent density (jsc) and fill factor (F.F.), and thus increased the conversion efficiency $\left(\eta^{S}\right)$ of solar cells (Fig. 11b, and conditions $\mathrm{d}$ and e in Table 2). The decrease of particle density and size of Pt particles (Figs. $8 \mathrm{~d}$ and e, and conditions $\mathrm{f}$ and $\mathrm{g}$ in Table 1, respectively) increased photocurrent density (jsc) and conversion efficiency $\left(\eta^{\varsigma}\right)$ (Fig. 11c, and conditions $\mathrm{f}$ and $\mathrm{g}$ in Table 2). The conversion efficiency of solar cells reached $7.3 \%$ of curve $c$ in Fig. 11 and $6.1 \%$ in the average of 4 samples (Table 2), and the etching time was shortened to $6.5 \mathrm{~h}$ from $24 \mathrm{~h}$ by controlling the photoillumination intensity and the dissolved oxygen concentration during etching (condition $\mathrm{g}$ in Table 1 and 2).

\begin{tabular}{|c|c|c|c|c|c|}
\hline $\begin{array}{c}\text { Preparation } \\
\text { conditions see } \\
\text { Table 1 }\end{array}$ & $\begin{array}{c}\text { No. of } \\
\text { tested } \\
\text { samples }\end{array}$ & $\begin{array}{c}\text { Open-circuit } \\
\text { photovoltage } \\
V_{\text {OC }}(\mathrm{V})\end{array}$ & $\begin{array}{c}\text { Short-circuit } \\
\text { photocurrent density } \\
j_{\text {SC }}\left(\mathrm{mA} \mathrm{cm}^{-2}\right)\end{array}$ & $\begin{array}{c}\text { Fill factor } \\
\text { F.F. }\end{array}$ & $\begin{array}{c}\text { Efficiency } \\
\eta^{S}(\%)\end{array}$ \\
\hline $\mathrm{a}$ & 21 & 0.47 & 13.8 & 0.60 & 3.9 \\
\hline $\mathrm{b}$ & 7 & 0.50 & 16.6 & 0.62 & 5.1 \\
\hline $\mathrm{d}$ & 17 & 0.46 & 17.6 & 0.60 & 4.9 \\
\hline $\mathrm{e}$ & 3 & 0.50 & 17.4 & 0.63 & 5.5 \\
\hline $\mathrm{f}$ & 3 & 0.49 & 18.0 & 0.66 & 5.8 \\
\hline $\mathrm{g}$ & 4 & 0.50 & 19.5 & 0.63 & 6.1 \\
\hline
\end{tabular}

Table 2. Characteristics of photovoltaic photoelectrochemical solar cells equipped with Pt-nanoparticle modified porous multicrystalline n-Si electrode prepared under the conditions in Table 1. Average values are indicated.

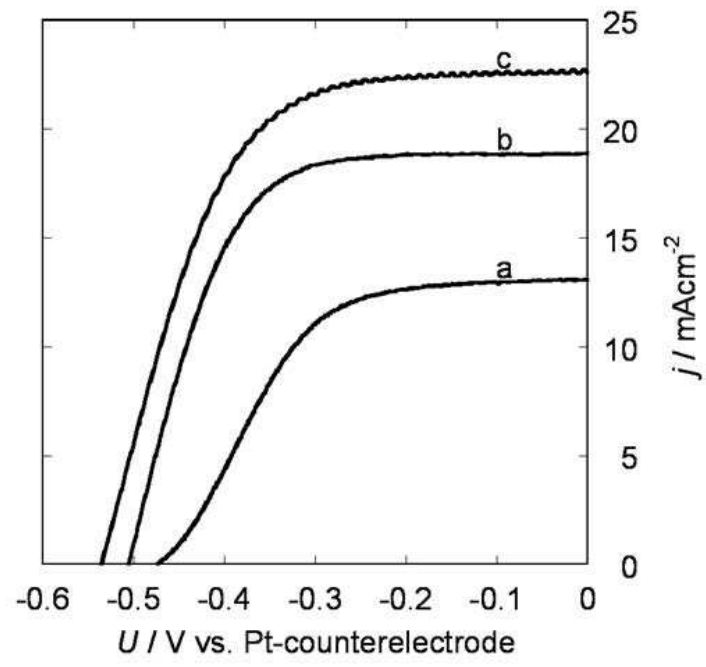

Fig. 11. Photocurrent density versus potential $(j-U)$ curves of photovoltaic photoelectrochemical solar cells equipped with a Pt-nanoparticle modified porous multicrystalline n-Si electrode. Preparation conditions: curves a, b, and c, are for conditions c, d, and g listed in Table 1, respectively. 
The increase in photocurrent density of photoelectrochemical solar cells equipped with Ptnanoparticle modified multicrystalline n-Si electrode by the Pt-particle-assisted hydrofluoric acid etching is ca. $15 \%$ lower than the $30-40 \%$ estimated with reduction of the reflectance from $33 \%$ to $5-14 \%$ at the light wavelength of $700 \mathrm{~nm}$. This difference can be explained by the difference in the refractive index between air (1.000), water (1.332 at $633 \mathrm{~nm})$ and Si (3.796 at $1.8 \mathrm{eV}(689 \mathrm{~nm})$ ) (Lide, 2004). The reflectance of $\mathrm{Si}$ is calculated at 34\% in the air and $23 \%$ in the water. Using $23 \%$ as the initial value of reflectance estimates the increase in photocurrent density by the etching at $12-23 \%$. This value is consistent with the experimental result of ca. $15 \%$.

The photovoltage of photoelectrochemical solar cells equipped with Pt-nanoparticle modified multicrystalline n-Si electrode was improved by formation of the porous layer by Pt-particle-assisted hydrofluoric acid etching (Table 2). The photovoltage increase by the etching in dark conditions for $24 \mathrm{~h}$ was $0.01 \mathrm{~V}\left(V_{\mathrm{OC}}: 0.43 \mathrm{~V}\right)$ in the average of eight samples, much lower than the $0.05 \mathrm{~V}\left(V_{\mathrm{OC}}: 0.47 \mathrm{~V}\right)$ by the etching in a laboratory without light control (condition a in Table 1 and 2). These results show that the microporous layer effectively increases the photovoltage of such photoelectrochemical solar cells. This increase is explained by the following two possible mechanisms. 1) Screening Pt-nanoparticles' modulation of Si surface band energies by the microporous layer: The photovoltage of an nSi electrode modified with metal particles depends on the distribution density of metal particles and the size of the direct metal-Si contacts. While metal particles are necessary as electrical conducting channels and catalysts of electrochemical reactions, the particles modulate the Si surface band energies. Thus, larger direct metal-Si contacts than a suitable size and/or a higher distribution density of metal particles than a suitable value reduce the effective energy barrier height, and then reduce the photovoltage of solar cells. The presence of a moderately thick microporous layer between the metal particles and bulk n-Si screens the modulation and thus raises the energy barrier height of the n-Si electrode, as discussed in the previous paper (Kawakami et al., 1997). 2) Increase in density of termination of Si surface bonds with iodine atoms: As we discussed in the previous section, the low opencircuit photovoltage $(0.42 \mathrm{~V})$ of the flat (nonporous) multicrystalline $\mathrm{n}$-Si electrodes can be caused by the insufficient density of the termination of Si surface bonds with iodine atoms. Using the hydrobromic acid and bromine electrolyte solution increased the average opencircuit photovoltage of porous n-Si electrodes prepared under the condition a in Table 1 by $0.03 \mathrm{~V}$ for multicrystalline and $0.02 \mathrm{~V}$ for single-crystalline $\mathrm{n}$-Si from those of using hydroiodic acid and iodide electrolyte solution. This result indicates that the density of the termination of the multicrystalline $\mathrm{n}-\mathrm{Si}$ surface bonds with iodine atoms is increased to sufficient value for generating high $V_{\mathrm{OC}}$ by forming the microporous layer.

\subsection{Solar to chemical conversion (solar hydrogen production)}

In the preceding section, we prepared the efficient photovoltaic photoelectrochemical solar cells using the Pt-nanoparticle modified porous multicrystalline n-Si electrode. In this section, these electrodes were used for solar to chemical conversion via the photoelectrochemical decomposition of hydrogen iodide $(\mathrm{HI})$ to iodine $\left(\mathrm{I}_{2}\right.$ or $\left.\mathrm{I}_{3}{ }^{-}\right)$and hydrogen gas $\left(\mathrm{H}_{2}\right)$, that is, solar hydrogen. A two-compartment cell was used (Fig. 1b). The multicrystalline n-Si electrode was used as a photoanode in the mixed solution of hydroiodic acid and iodine of the anode compartment. A platinum plate was used as a counterelectrode in the perchloric acid $\left(\mathrm{HClO}_{4}\right)$ solution of the cathode compartment. Both compartments were separated with a porous glass plate. Figure 12 shows the typical photocurrent density versus potential $(j-U)$ curve for the 
multicrystalline n-Si electrode prepared under the condition $g$ in Table 1 and 2. The potential $(U)$ of the electrode was measured versus the Pt-plate counterelectrode in the perchloric acid solution of the cathode compartment (Fig. 1b). The short-circuit photocurrent density of 21.7 $\mathrm{mA} \mathrm{cm}-2$ was obtained. The solution color at the Si surface darkened, and gas evolution occurred at the Pt cathode surface. These results clearly show that the photoelectrochemical solar cell equipped with the Pt-nanoparticle modified porous multicrystalline n-Si electrode can decompose hydrogen iodide into hydrogen and iodine with no external bias, as shown in the equations (1), (2) and (3) in the section 1.1.

The dashed curve in Fig. 12 shows the current density versus the potential $(j-U)$ curve of $\mathrm{Pt}$ electrode, which was in the anode compartment, instead of the Si electrode of the above cell for hydrogen iodide decomposition (Fig. 1b). The onset potential of the anodic current was $0.25 \mathrm{~V}$ versus the Pt-counterelectrode in the cathode compartment. This value indicates that the Gibbs energy change for the hydrogen iodide decomposition in the present solutions is $0.25 \mathrm{eV}$. The energy gain of solar to chemical conversion using the photoelectrochemical solar cell is calculated at $5.4 \mathrm{~mW} \mathrm{~cm}^{-2}$ by the product of the Gibbs energy change per the elementary charge and the short-circuit photocurrent density of $21.7 \mathrm{~mA} \mathrm{~cm}^{-2}$ under simulated solar illumination (AM1.5G, $100 \mathrm{~mW} \mathrm{~cm}^{-2}$ ). Thus, we calculate the efficiency of solar to chemical conversion (solar hydrogen production) via the photoelectrochemical decomposition of hydrogen iodide at $5.4 \%$. The average in solar-to-chemical-conversion efficiency of five samples was $4.7 \%$.

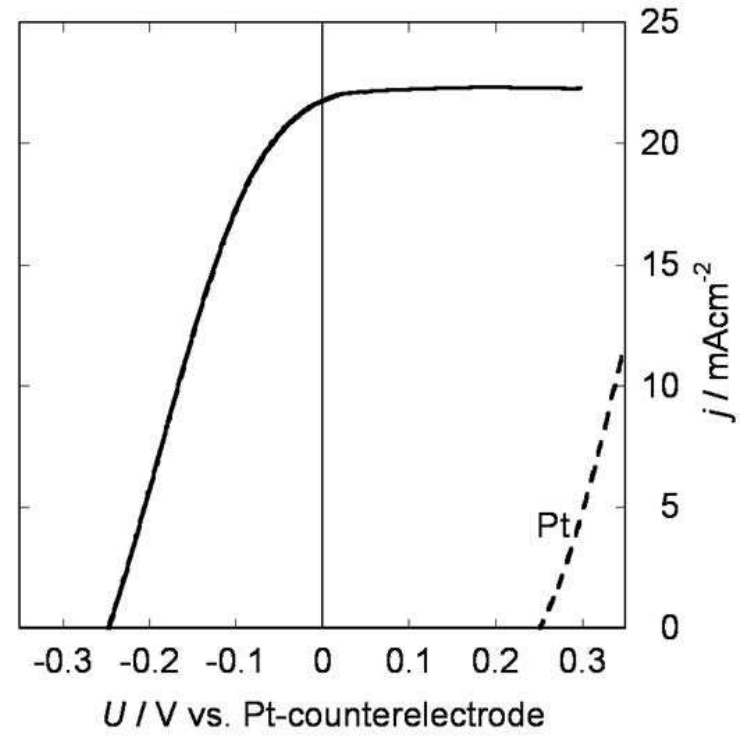

Fig. 12. Photocurrent density versus potential $(j-U)$ curve (solid line) for solar-to-chemical conversion type of photoelectrochemical solar cell equipped with Pt-nanoparticle modified porous multicrystalline n-Si electrode prepared under condition g in Table 1. The twocompartment cell for photodecomposition of hydrogen iodide (Fig. 1b) was used. Dashed line: Pt electrode measured in the anode compartment of the two-compartment cell instead of the Si photoelectrode. 
In Section 2, it was described that platinum-nanoparticle modified porous multicrystalline silicon electrodes prepared by electroless displacement deposition and metal-particleassisted hydrofluoric acid etching can generate hydrogen (solar hydrogen) and iodine through the photoelectrochemical decomposition of hydrogen iodide in aqueous solution with no external bias at the solar-to-chemical conversion efficiency of $5.4 \%$. The control of particle density and size of Pt particles by changing the initial surface condition of Si and deposition condition of $\mathrm{Pt}$, and the control of porous layer structure by changing the etching conditions improve the conversion efficiency.

\section{Platinum nanoparticle modified microcrystalline silicon thin films}

Hydrogenated microcrystalline silicon $(\mu \mathrm{c}-\mathrm{Si}: \mathrm{H})$ thin films are promising new materials for low-cost solar cells. The microcrystalline Si thin film approach has several advantages, including minimal use of semiconductor resources, large-area fabrication using low-cost chemical vapor deposition (CVD) methods, and no photodegradation of the solar cell's characteristics (Matsumura, 2001, Meier et al., 1994, Yamamoto et al., 1994). We applied microcrystalline $\mathrm{Si}$ thin films to solar hydrogen production by the photodecomposition of hydrogen iodide (Yae et al., 2007a, 2007b) and solar water splitting(Yae et al., 2007b). Figure 13 schematically shows a cross-section of the microcrystalline silicon thin-film photoelectrode. Photoelectrochemical solar cells require neither a p-type semiconductor layer nor a transparent conducting layer, which is necessary to fabricate solid-state solar cells.

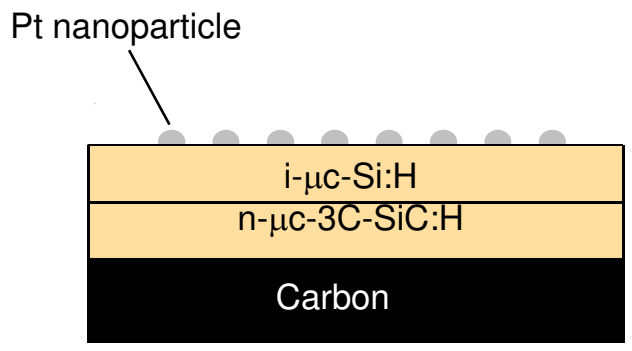

Fig. 13. Schematic cross-section of Pt-nanoparticle modified microcrystalline Si thin-film photoelectrode.

3.1 Preparation of photoelectrodes and photovoltaic photoelectrochemical solar cells Hydrogenated microcrystalline silicon thin films were deposited onto polished glassy carbon (Tokai Carbon) substrates by the hot-wire catalytic chemical vapor deposition (catCVD) method (Matsumura et al. 2003). A 40-nm-thick n-type hydrogenated microcrystalline cubic silicon carbide (n- $\mu \mathrm{c}-3 \mathrm{C}-\mathrm{SiC}: \mathrm{H})$ layer was deposited on the substrates using hydrogendiluted monomethylsilane and phosphine gas at temperatures of $1700^{\circ} \mathrm{C}$ for the rhenium filament. An intrinsic hydrogenated microcrystalline silicon (i- $\mu \mathrm{c}-\mathrm{Si}: \mathrm{H})$ layer, with thickness of 2-3 $\mu \mathrm{m}$, was deposited on the n-type layer using monosilane gas at $1700^{\circ} \mathrm{C}$ for the tantalum filament. The microcrystalline silicon thin film electrodes were prepared by connecting a copper wire to the backside of the substrate with silver paste and covering it with insulating epoxy resin. 
We deposited the Pt nanoparticles on the microcrystalline silicon surface using electroless displacement deposition as for the multicrystalline Si photoelectrodes (section 2.1). Figure 14 shows an scanning electron microscopic (SEM) image of the microcrystalline silicon film's surface after immersion in the Pt deposition solution for $120 \mathrm{~s}$. Platinum nanoparticles of 3$200 \mathrm{~nm}$ in size and $1.5 \times 10^{10} \mathrm{~cm}^{-2}$ in particle density were scattered on the film. The size and distribution density of $\mathrm{Pt}$ particles varied with the deposition conditions, such as oxide layer formation on the films before deposition and the immersion time of films in the deposition solution. The distribution density is much higher than that for a single-crystalline n-Si wafer, but the changing behaviors of the size and distribution density are similar to those of the single crystalline (Yae et al., 2007c, 2008).

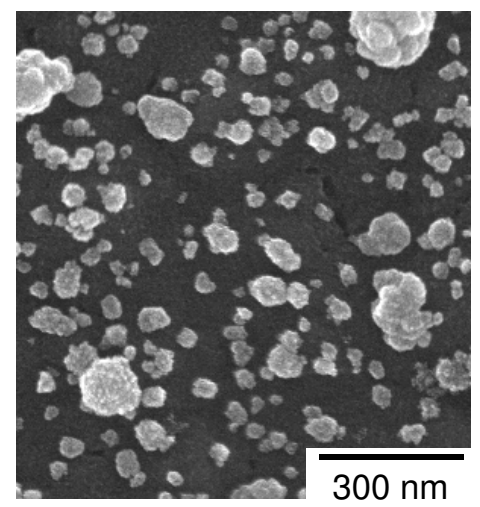

Fig. 14. Scanning electron microscopic image of Pt-nanoparticle modified microcrystalline Si thin film surface.

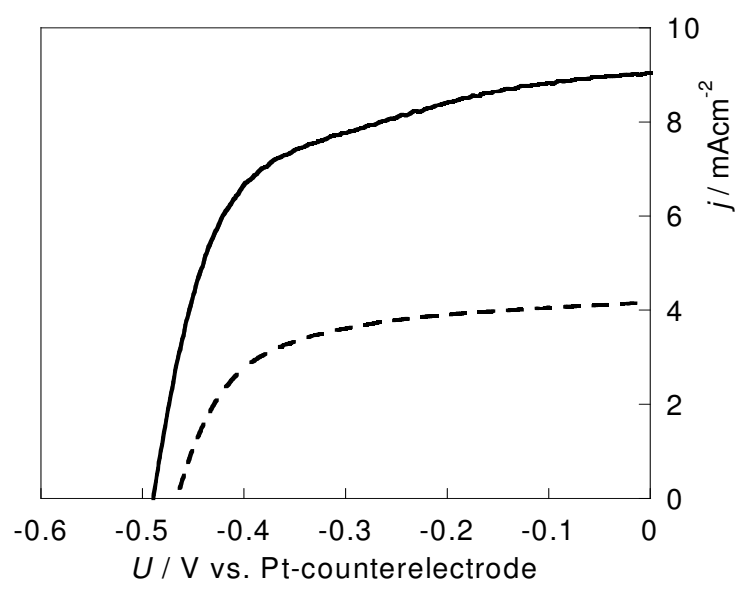

Fig. 15. Photocurrent density versus potential $(j-U)$ curves for photovoltaic photoelectrochemical solar cell equipped with the Pt-nanoparticle modified microcrystalline Si photoelectrode measured in the $7.6 \mathrm{~mol} \mathrm{dm}^{-3}(\mathrm{M})$ hydroiodic acid $(\mathrm{HI}) / 0.05 \mathrm{M}$ iodine $\left(\mathrm{I}_{2}\right)$ (dashed line) and 3.0 M HI/0.002 $\mathrm{M} \mathrm{I}_{2}$ (solid line) redox solutions. 
For the photovoltaic photoelectrochemical solar cell (Fig. 1a), the Pt-nanoparticle-modified microcrystalline silicon thin film electrode and Pt-plate counterelectrode were immersed in a hydroiodic acid and iodine redox electrolyte solution as for the multicrystalline $\mathrm{Si}$ photoelectrodes (section 2.3). Figure 15 shows the photocurrent density versus potential $(j-U)$ curves for the photovoltaic solar cell. The microcrystalline silicon film was stably adherent to the glassy carbon substrate after completing the photoelectrochemical measurements in these highly acidic solutions. The open-circuit photovoltage was 0.47-0.49 $\mathrm{V}$. This is higher than the $0.3 \mathrm{~V}$ value obtained for the microcrystalline silicon thin film electrode covered with a continuous 1.5-nm-thick Pt layer, which was deposited using the electron-beam evaporation method. These results clearly indicate that the Pt-nanoparticlemodified microcrystalline silicon thin film electrodes work by using the same mechanism as the Pt-nanoparticle-modified single-crystalline n-Si electrodes, which work as ideal semiconductor photoelectrodes for generating high photovoltage and stable photocurrent described in previous sections 1.2 and 2.3.1. The reduction of redox electrolyte concentration increased the short-circuit photocurrent density to 9.1 from $4.2 \mathrm{~mA} \mathrm{~cm}^{-2}$ (Fig. 15, solid line). This increase is caused by a decrease in the visible light absorption of the triiodide $\left(\mathrm{I}_{3}^{-}\right)$ion in the redox solution. The increased photocurrent raised open-circuit photovoltage to $0.49 \mathrm{~V}$, and thus the photovoltaic conversion efficiency reached $2.7 \%$.

\subsection{Solar to chemical conversion (solar hydrogen production) via hydrogen iodide decomposition}

The Pt-nanoparticle modified microcrystalline Si thin film electrode were used for solar to chemical conversion via the photoelectrochemical decomposition of hydrogen iodide to iodine and hydrogen gas as the multicrystalline $\mathrm{Si}$ photoelectrodes (section 2.4). For the photoelectrochemical decomposition of hydrogen iodide, a two-compartment cell was used (Fig. $1 \mathrm{~b}$ and 2).

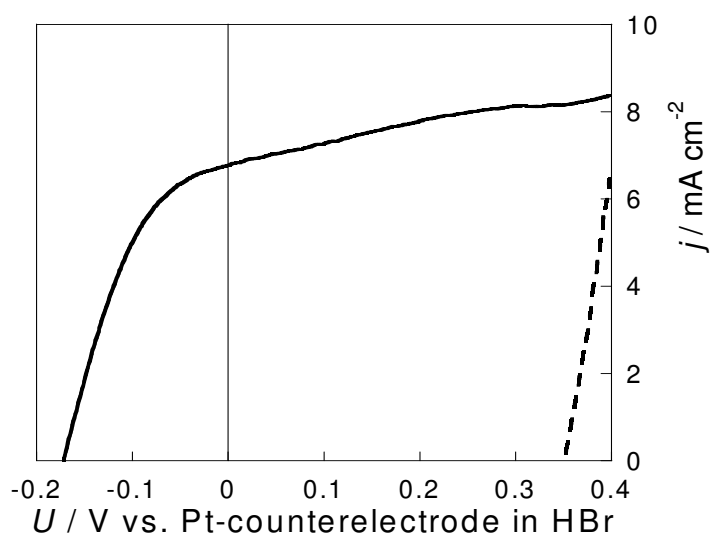

Fig. 16. Photocurrent density versus potential $(j-U)$ curve (Solid line) for the Pt-nanoparticle modified microcrystalline $\mathrm{Si}$ thin film electrode measured in the hydroiodic acid and iodine mixture solution of the anode compartment of the two-compartment cell for solar to chemical conversion (solar hydrogen production, Fig. 1b). Dashed line: Pt electrode measured in the anode compartment of the two-compartment cell instead of the Si photoelectrode. Electrolyte solutions: anode compartment: 3.0 M HI/0.002 $\mathrm{M} \mathrm{I}_{2}$; cathode compartment: 3.0 M HBr. 
The solid line in Fig. 16 shows the photocurrent density versus potential $(j-U)$ curve for the Pt-nanoparticle-modified microcrystalline Si thin film electrode measured in the hydroiodic acid and iodine mixture solution of the anode compartment of the two-compartment cell. The potential of the electrode was measured versus the $\mathrm{Pt}$ counterelectrode in the hydrobromic acid solution of the cathode compartment. In the short-circuit condition under the simulated solar illumination, we obtained a shirt-circuit photocurent density of $6.8 \mathrm{~mA}$ $\mathrm{cm}^{-2}$, the solution color on the photoelectrode surface darkened, and gas evolution occurred at the Pt cathode surface. These results clearly show that the photoelectrochemical solar cell equipped with the Pt-nanoparticle-modified microcrystalline Si thin film electrode can decompose hydrogen iodide into hydrogen gas and iodine with no external bias with $2.3 \%$ of solar-to-chemical conversion efficiency.

\subsection{Hydrogen production via solar water splitting using multi-photon system}

A multi-photon system equipped with the microcrystalline $\mathrm{Si}$ thin film and titanium dioxide $\left(\mathrm{TiO}_{2}\right)$ photoelectrodes in series (Fig. 17) was prepared based on a work in literature using a dye-sensitization-photovoltaic cell and a tungsten trioxide $\left(\mathrm{WO}_{3}\right)$ photoanode (Grätzel, 1999). A titanium dioxide photoanode and a Pt cathode (counterelectrode) were immersed in a perchloric acid $\left(\mathrm{HClO}_{4}\right)$ aqueous solution in a quartz cell. A photovoltaic photoelectrochemical solar cell equipped with the Pt-nanoparticle-modified microcrystalline Si electrode (section 3.1) was connected to the titanium dioxide photoanode and Pt cathode in series. Simulated solar light irradiated to the titanium dioxide photoelectrode. The titanium dioxide, which has a 3-eV energy band gap, absorbs the short-wavelength part (UV) of the solar light. The long-wavelength part of the solar light transmitted by the titanium dioxide and quartz cell reaches the Pt-nanoparticle-modified microcrystalline Si thin-film of the photovoltaic photoelectrochemical solar cell. The photovoltaic cell applies bias between the titanium dioxide photoanode and the $\mathrm{Pt}$ cathode in a perchloric acid aqueous solution for splitting water to hydrogen and oxygen.

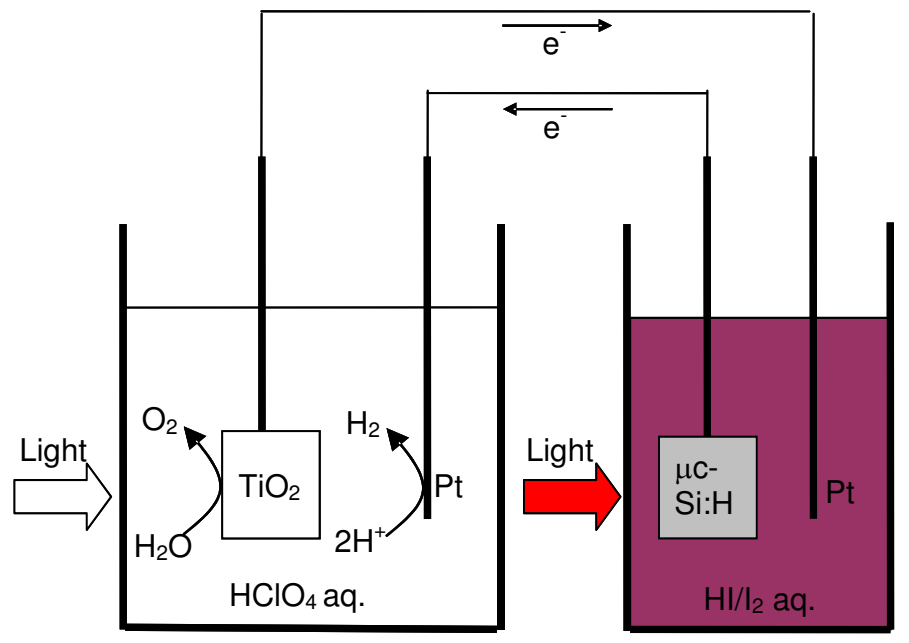

Fig. 17. Schematic illustration of multi-photon system equipped with titanium dioxide and microcrystalline Si photoelectrodes for solar water splitting. 
The titanium dioxide photoanode was prepared as follows. Transparent conductive tin oxide $\left(\mathrm{SnO}_{2}\right)$-coated glass plates were used as substrates. Titanium dioxide powder (P-25, average crystallite size: $21 \mathrm{~nm}$ ) was ground with nitric acid, acetyl acetone, surfactant (Triton X-100), and water in a mortar. The obtained paste was coated on the substrate and dried. The titanium dioxide-nanoparticle film was heated in air at $500^{\circ} \mathrm{C}$ for three hours. The titanium dioxide electrode was prepared by connecting a copper wire to the bare part of the conductive tin oxide film with silver paste and covering it with insulating epoxy resin.

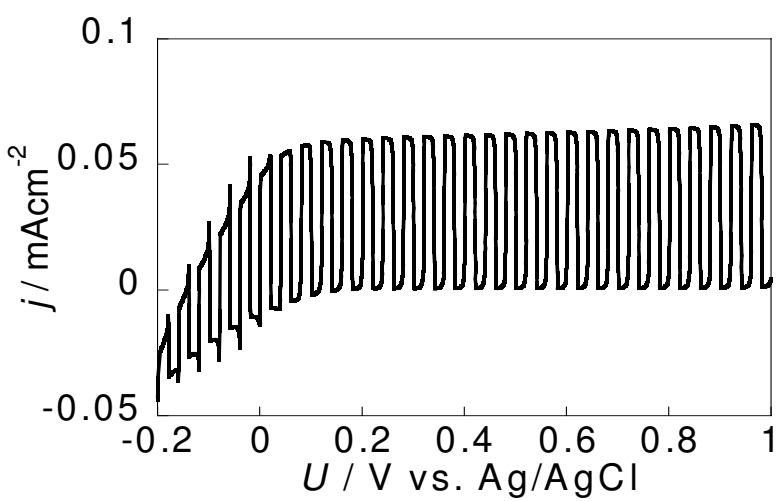

Fig. 18. Photocurrent density versus potential $(j-U)$ curve for the titanium dioxide photoelectrode in a perchloric acid aqueous solution under chopped simulated solar illumination.

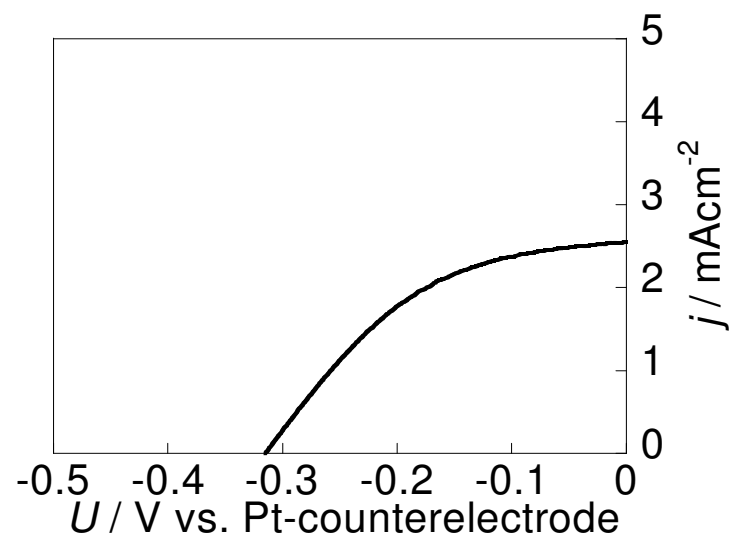

Fig. 19. Photocurrent density versus potential $(j-U)$ curve for the photovoltaic photoelectrochemical solar cell equipped with a Pt-nanoparticle-modified microcrystalline Si electrode in the redox solution under simulated solar light illumination through the titanium dioxide photoelectrochemical cell. 
Figure 18 shows the photocurrent density versus potential $(j-U)$ curve for the titanium dioxide photoelectrode in a perchloric acid aqueous solution under simulated solar illumination. The dissolved oxygen in the solution was eliminated by using argon gas flow into the solution before the measurement. The anodic photocurrent starts to generate at $-0.14 \mathrm{~V} \mathrm{vs}$. Ag/ $\mathrm{AgCl}$. This onset potential is more positive than $-0.24 \mathrm{~V}$ vs. $\mathrm{Ag} / \mathrm{AgCl}$ for hydrogen evolution, and thus this electrode cannot split water into hydrogen and oxygen without external bias. Figure 19 shows the photocurrent density versus potential $(j-U)$ curve for the photovoltaic photoelectrochemical solar cell equipped with a Pt-nanoparticle-modified microcrystalline Si electrode in the redox solution under simulated solar light illumination through the titanium dioxide photoelectrochemical cell. The shirt-circuit photocurrent density was decreased from $5.3 \mathrm{~mA} \mathrm{~cm}^{-2}$ for the cell under direct solar light illumination to $2.6 \mathrm{~mA} \mathrm{~cm}^{-2}$ by light attenuation with the titanium dioxide cell. The multi-photon system (Fig. 17) using the same titanium dioxide and Pt-nanoparticle-modified microcrystalline Si electrodes as those in Figs. 18 and 19 indicated the photocurrent density versus potential $(j-U)$ curve of Fig. 20. This system generated anodic photocurrent at a potential that was more negative than $-0.24 \mathrm{~V} \mathrm{vs}$. Ag/ $\mathrm{AgCl}$ for hydrogen evolution. Figure 21 shows that steady photocurrent was obtained for the multiphoton system in the short-circuit condition (Fig. 17). Tiny gas bubble formed on the Pt cathode during measurement under the short-circuit condition. These results show that this multi-photon system can split water into hydrogen and oxygen with no external bias with solar light. Since two photoelectrodes of titanium dioxide and Pt-nanoparticle-modified microcrystalline Si were connected in series, photovoltage was the sum of the two electrodes' values and photocurrent was the lower of the two electrodes' values. Therefore, the photocurrent density for water splitting was determined by that of the titanium dioxide electrode and very low. The photocurrent density, and thus hydrogen production by solar water splitting, is expected to increase by using a semiconductor with a narrower band gap, such as tungsten trioxide, instead of titanium dioxide. The theoretical simulation obtained $8 \mathrm{~mA} \mathrm{~cm}^{-2}$ of shirt-circuit photocurrent density, that is, $10 \%$ of solar-to-chemical conversion efficiency for solar water splitting for the tungsten trioxide and Si multi-photon system.

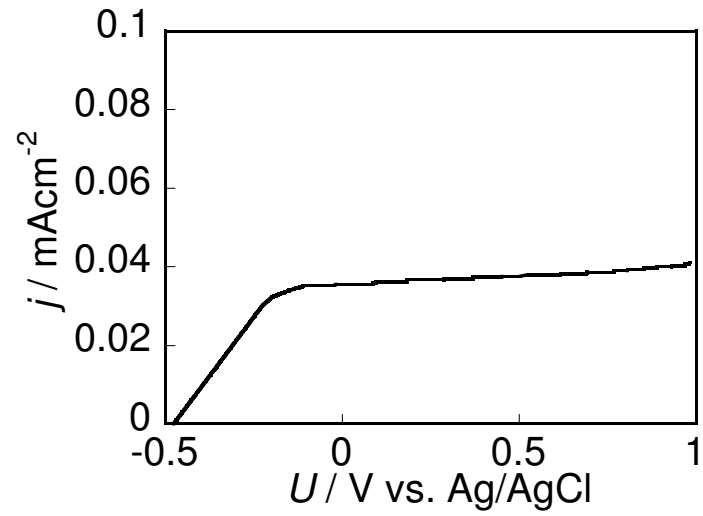

Fig. 20. Photocurrent density versus potential $(j-U)$ curve for the multi-photon system (Fig. 17) using the same titanium dioxide thin film and Pt-nanoparticle modified microcrystalline Si photoelectrodes and electrolyte solutions as those in Figs. 18 and 19 under simulated solar light illumination. 


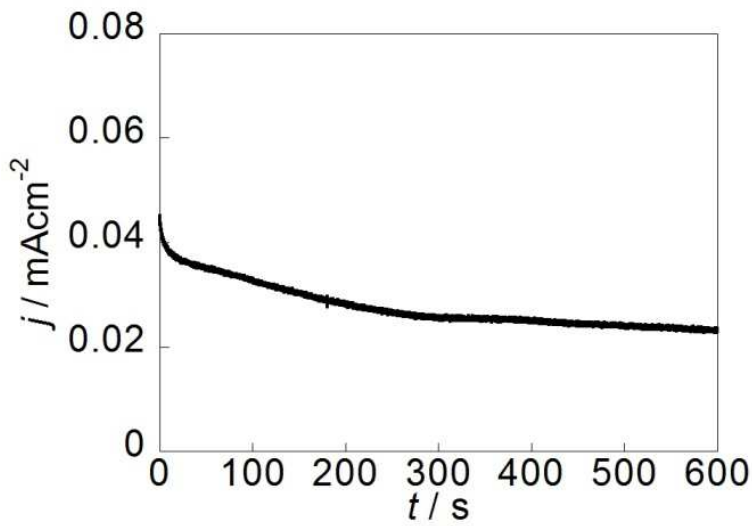

Fig. 21. Short-circuit photocurrent density $(j)$ as a function of time $(t)$ for the multi-photon system of Fig. 20 under simulated solar illumination.

\section{Conclusion}

Multicrystalline silicon wafers and microcrystalline silicon thin films, which are common and prospective low-cost semiconductor materials for solar cells, respectively, were successfully applied to produce solar hydrogen via photodecomposition of hydrogen iodide and solar water splitting. These photoelectrochemical solar cells have the following advantages: 1) simple fabrication of a cell by immersing the electrode in an electrolyte solution; 2) there is no need for a p-type semiconductor or a transparent conducting layer; and 3) direct solar-to-chemical conversion (fuel production). Modification of silicon surface with platinum nanopartilces by electroless displacement deposition and porous layer formation by metal-particle-assisted hydrofluoric acid etching improve solar cell characteristics. The solar-to-chemical conversion efficiency reached $5 \%$ for the photodecomposition of hydrogen iodide, and hydrogen gas evolution was obtained by the solar water splitting with no input of external electricity.

\section{Acknowledgment}

The author is grateful to Prof. H. Matsuda, Dr. N. Fukumuro (University of Hyogo), Dr. S. Ogawa, Prof. N. Yoshida, Prof. S. Nonomura (Gifu University), Mr. S. Sakamoto (Nippon Oikos Co., Ltd.), and Prof. Y. Nakato (Osaka University) for co-work and valuable discussions. The author would like to thank the students who collaborated: H. Miyasako, T. Kobayashi, K. Suzuki, and A. Onaka. The author is grateful to Prof. Y. Uraoka of Nara Institure of Science and Technology for the simulation of the solar water splitting using the multi-photon system. The present work was partly supported by the following programs: Grants-in-Aid for Scientific Research (C) from the JSPS (17560638, 20560676, and 23560875), Grants-in-Aid for education and research from Hyogo Prefecture through the University of Hyogo, Core Research for Evolutional Science and Technology (CREST) from the Japan Science and Technology Agency (JST), and Research for Promoting Technological Seeds from JST. The author wishes to thank Nippon Sheet Glass Co., Ltd. for donating transparent conductive tin oxide coated glass plates. Figures 15 and 16 were reprinted from ref. Yae et al., 2007a, copyright Elsevier (2007). 


\section{References}

Allongue, P., Blonkowski, S., \& Souteyrand, E. (1992). Elecrochim. Acta, Vol. 37, 781.

Arakawa, H., Shiraishi, C., Tatemoto, M., Kishida, H., Usui, D., Suma, A., Takamisawa, A., \& Yamaguchi, T. (2007). Proc. SPIE, Vol. 6650, Solar Hydrogen and Nanotechnology II, Guo, J. (Ed.), San Diego, 665003.

Chemla, M., Homma, T., Bertagna, V., Erre, R., Kubo, N., \& Osaka, T. (2003). J. Electroanal. Chem., Vol. 559, 111.

Fujishima, A. \& Honda, K. (1972). Nature, Vol. 238, 37.

Fujitani, M., Hinogami, R., Jia, J. G., Ishida, M., Morisawa, K., Yae, S., \& Nakato, Y. (1997). Chem. Lett., 1041.

Grätzel, M. (1999). Cattech, Vol. 3, 4.

Gorostiza, P., Servat, J., Morante, J. R., \& Sanz, F. (1996). Thin Solid Films, Vol. 275, 12.

Gorostiza, P., Allongue, P., Díaz, R.; Morante, J. R., \& Sanz, F. (2003). J. Phys. Chem. B, Vol. $107,6454$.

Hinogami, R., Nakamura, Y., Yae, S., \& Nakato, Y. (1997). Appl. Surf. Sci., Vol. 121/122, 301.

Hinogami, R., Nakamura, Y., Yae, S., \& Nakato, Y. (1998). J. Phys. Chem. B, Vol. 102, 974.

Ishida, M., Morisawa, K., Hinogami, R., Jia, J. G., Yae, S., \& Nakato, Y. (1999). Z. Phys. Chem., Vol. 212, 99.

Jia, J.-G., Fujitani, M., Yae, S., \& Nakato, Y. (1996). Electrochim. Acta, Vol. 42, 431.

Kawakami, K., Fujii, T., Yae S., \& Nakato, Y. (1997). J. Phys. Chem. B, Vol. 101, 4508.

Khaselev, O. \& Turner, J. A. (1998). Science, Vol. 280, 542.

Licht, S. (Vol. Ed.). (2002). Semiconductor Electrodes and Photoelectrochemistry, Bard. A. J. \& Stratmann, M. (Series Eds.), Encyclopedia of Electrochemistry, Vol. 6, Wiley-VCH, Weinheim.

Lide, D. R. (Ed.). (2004). CRC Handbook of Chemistry and Physics, CRC Press, Boca Raton, 85th Ed., pp. 10-232, 10-234 and 12-150.

Lin, G. H., Kapur, M., Kainthla, R. C., \& Bockris, J. O'M. (1989). Appl. Phys. Lett., Vol. 55, 386.

Matsumura, H. (2001). Thin Solid Films, Vol. 395, 1.

Matsumura, H., Umemoto, H., Izumi, A., \& Masuda, A. (2003). Thin Solid Films, Vol. 430, 7.

Meier. J., Flückiger, R., Keppner, H., \& Shah, A. (1994). Appl. Phys. Lett., Vol. 65, 860.

Miller, E. L., Marsen, B., Paluselli, D., \& Rocheleau, R. (2005). Electrochem. Solid-State Lett., Vol. 8, A247.

Nagahara, L. A., Ohmori, T., Hashimoto, K., \& Fujishima, A. (1993). J. Vac. Sci. Technol. A, Vol. 11, 763.

Nakato, Y., Ueda, K., Yano, H., \& Tsubomura, H. (1988). J. Phys. Chem., Vol. 92, 2316.

Nakato, Y. \& Tsubomura, H. (1992). Elecrochim. Acta, Vol. 37, 897.

Nakato, Y., Jia, J. G., Ishida, M., Morisawa, K., Fujitani, M., Hinogami, R., \& Yae, S. (1998). Electrochem. Solid-State Lett., Vol. 1, 71.

Nakato, Y. (2000). Photoelectrochemical Cells, In: Wiley Encyclopedia of Electrical and Electronics Engineering Online, Webster, J. (Ed.), John Wiley \& Sons, Available from: http:/ / www.interscience.wiley.com

Nelson, J. (2003). The Physics of Solar Cells, Imperial College Press, London, pp. 276-279.

Paunovic, M., Schlesinger, M. (2006). Fundamentals of Electrochemical Deposition 2nd. Ed., John Wiley \& Sons, New York. 
Park, J. H. \& Bard, A. J. (2005). Electrochem. Solid-State Lett., Vol. 8, G371.

Sakai, Y., Sugahara, S., Matsumura, M., Nakato, Y., \& Tsubomura, H. (1988). Can. J. Chem., Vol. 66, 1853.

Sze, S. M. (1981). Physics of Semiconductor Devices, John Wiley \& Sons, New York, 2nd Ed., pp. 811-816.

Takabayashi, S., Nakamura, R., \& Nakato, Y. (2004). J. Photochem. Photobiol. A, Vol. 166, 107.

Takabayashi, S., Imanishi, A., \& Nakato, Y. (2006). Comptes Rendus Chimie, Vol. 9, 275.

Turner, J. A., Williams, M. C., \& Rajeshwar, K. (2004). Interface, Vol. 13, No. 3, 24.

Yae, S., Tsuda, R., Kai, T., Kikuchi, K., Uetsuji, M., Fujii, T., Fujitani, M., \& Nakato, Y. (1994). J. Electrochem. Soc., Vol. 141, 3090.

Yae, S., Nakanishi, I., Nakato, Y., Toshima, N., \& Mori, H. (1994). J. Electrochem. Soc., Vol. $141,3077$.

Yae, S., Fujitani, M., Nakanishi, I., Uetsuji, M., Tsuda, R., \& Nakato, Y. (1996). Sol. Energy Mater. Sol. Cells, Vol. 43, 311.

Yae, S., Kitagaki, M., Hagihara, T., Miyoshi, Y., Matsuda, H., Parkinson, B. A., \& Nakato, Y. (2001). Electrochim. Acta, Vol. 47, 345.

Yae, S., Kawamoto, Y., Tanaka, H., Fukumuro, N., \& Matsuda, H. (2003). Electrochem. Comm., Vol. 5, 632.

Yae, S., Tanaka, H., Kobayashi, T., Fukumuro, N., \& Matsuda, H. (2005). Phys. Stat. Sol. (c), Vol. 2, 3476.

Yae, S., Kobayashi, T., Kawagishi, T., Fukumuro, N., \& Matsuda, H. (2006). Solar Energy, Vol. 80,701 .

Yae, S., Kobayashi, T., Kawagishi, T., Fukumuro, N., \& Matsuda, H. (2006). The Electrochemical Society Proceedings Series, Vol. PV2004-19, Pits and Pores III: Formation, Properties and Significance for Advanced Materials, Schmuki, P., Lockwood, D. J., Ogata, Y. H., Seo, M., \& Isaacs, H. S. (Eds.). 141.

Yae, S., Kobayashi, T., Abe, M., Nasu, N., Fukumuro, N., Ogawa, S., Yoshida, N., Nonomura, S., Nakato, Y., \& Matsuda, H. (2007). Sol. Energy Mater. Sol. Cells, Vol. 91, 224.

Yae, S., Onaka, A., Abe, M., Fukumuro, N., Ogawa, S., Yoshida, N., Nonomura, S., Nakato, Y., \& Matsuda, H. (2007). Proc. SPIE, Vol. 6650, Solar Hydrogen and Nanotechnology II, Guo, J. (Ed.), San Diego, 66500E.

Yae, S., Nasu, N., Matsumoto, K., Hagihara, T., Fukumuro, N., \& Matsuda, H. (2007). Electrochim. Acta, Vol. 53, 35.

Yae, S., Abe, M., Kawagishi, T., Suzuki, K., Fukumuro, N., \& Matsuda, H. (2007). Trans. Mater. Res. Soc. Jpn., Vol. 32, 445.

Yae, S., Fukumuro, N., \& Matsuda, H. (2008). Electrochemical Deposition of Metal Nanoparticles on Silicon, In: Progress in Nanoparticles Research, Frisiras, C. T. (Ed.), pp. 117-135, Nova Science Publishers, Inc., New York.

Yae, S., Fukumuro, N., \& Matsuda, H. (2009). Porous Silicon Formation by Metal Particle Enhanced HF etching, In: Electroanalytical Chemistry Research Trends, Hayashi, K. (Ed.), pp. 107-126, Nova Science Publishers, New York.

Yae, S., Tashiro, M., Abe, M., Fukumuro, N., \& Matsuda, H. (2010). J. Electrochem. Soc., Vol. 157, D90. 
Yamamoto, K., Nakashima, A., Suzuki, T., Yoshimi, M., Nishio, H., \& Izumina, M. (1994). Jpn. J. Appl. Phys. Vol. 33, L1751.

Zhou, X., Ishida, M., Imanishi, A., \& Nakato, Y. (2001). J. Phys. Chem. B, Vol. 105, 156. 


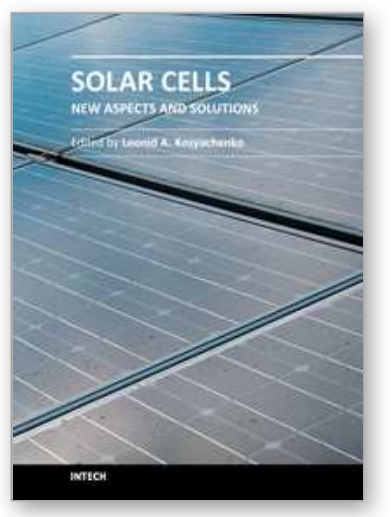

\author{
Solar Cells - New Aspects and Solutions \\ Edited by Prof. Leonid A. Kosyachenko
}

ISBN 978-953-307-761-1

Hard cover, 512 pages

Publisher InTech

Published online 02, November, 2011

Published in print edition November, 2011

The fourth book of the four-volume edition of 'Solar cells' consists chapters that are general in nature and not related specifically to the so-called photovoltaic generations, novel scientific ideas and technical solutions, which has not properly approved. General issues of the efficiency of solar cell and through hydrogen production in photoelectrochemical solar cell are discussed. Considerable attention is paid to the quantum-size effects in solar cells both in general and on specific examples of super-lattices, quantum dots, etc. New materials, such as cuprous oxide as an active material for solar cells, AlSb for use as an absorber layer in $p$-i-n junction solar cells, InGaAsN as a promising material for multi-junction tandem solar cells, InP in solar cells with MIS structures are discussed. Several chapters are devoted to the analysis of both status and perspective of organic photovoltaics such as polymer/fullerene solar cells, poly( $p$-phenylene-vinylene) derivatives, photovoltaic textiles, photovoltaic fibers, etc.

\title{
How to reference
}

In order to correctly reference this scholarly work, feel free to copy and paste the following:

Shinji Yae (2011). Solar to Chemical Conversion Using Metal Nanoparticle Modified Low-Cost Silicon Photoelectrode, Solar Cells - New Aspects and Solutions, Prof. Leonid A. Kosyachenko (Ed.), ISBN: 978-953307-761-1, InTech, Available from: http://www.intechopen.com/books/solar-cells-new-aspects-andsolutions/solar-to-chemical-conversion-using-metal-nanoparticle-modified-low-cost-silicon-photoelectrode

\section{INTECH}

open science | open minds

\section{InTech Europe}

University Campus STeP Ri

Slavka Krautzeka 83/A

51000 Rijeka, Croatia

Phone: +385 (51) 770447

Fax: +385 (51) 686166

www.intechopen.com

\section{InTech China}

Unit 405, Office Block, Hotel Equatorial Shanghai

No.65, Yan An Road (West), Shanghai, 200040, China

中国上海市延安西路65号上海国际贵都大饭店办公楼 405 单元

Phone: +86-21-62489820

Fax: $+86-21-62489821$ 
(C) 2011 The Author(s). Licensee IntechOpen. This is an open access article distributed under the terms of the Creative Commons Attribution 3.0 License, which permits unrestricted use, distribution, and reproduction in any medium, provided the original work is properly cited. 